\title{
Potentials of Information and Communication Technologies for Poverty Alleviation and Food Security
}

\author{
Adeniji, O. B \\ Department of Agricultural Economics and Extension Technology, \\ Federal University of Technology, \\ Minna, Niger State. \\ E-mail: bolajiadeniji@yahoo.com
}

\begin{abstract}
The paper examined the potentials and benefits of Information and Communication Technologies (ICTs) as a means of enhancing food security and alleviating poverty in Nigeria. Access to information and improved communication is a crucial requirement for sustainable development. The paper describes how ICTs could be utilized to enhance small holders production. This is done with a particular focus on the bourgeoning ICTs interface in Nigeria. The paper looked at the utility levels of ICT. The paper posit that ICT sector is cross-cutting and each sector has to find the best way of using ICTs to help meet the challenges in a globalize world. The paper concludes by ascertaining that much still need to be done to annex the communication for extension of agricultural messages in the rural areas. There is the need to pursue policy that would enhance usages of ICT to avoid being left in the digital world.
\end{abstract}

\section{INTRODUCTION}

Information technologies (IT) has been described as the acquisition ,processing, storage and dissemination of vocal, pictorial, textual and numeric information by a micro electronic based to a combination of computers and telecommunication (CTA 2006). All human activities entail communication of various kinds. Communication is required to keep various group that are involved in each activities. Communication involves creating, sending and receiving, understanding and using information in various forms. In essence, information is central to all human activities.

Asian Development Bank (ADB) (2003) defined ICT as a set of activities that facilitates by electronic means the processing. transmission and display of information. While Greenidge (2003) defined ICTs as those technologies that can be used to interlink information technologies devices such as personal computers with communication technologies such as telephones and tele- communication networks. However, the term ICTs has assumed a wider dimension covering multitude of media like telephones, television, radio, video, telex, voice information systems, fax, personal computers and the internets. 
Rural Nigeria is dominated by people whose livelihood revolves around agricultural production and food processing. However food insecurity and poverty are common feature of these people. The role of information is well known in development circle. In agricultural sector, the demand for new information gave birth to agricultural extension services, whose main goal is transferring information from global knowledge base and local research to farmers, enabling them to clarify their own goals and possibilities, educating them on how to make better decisions and stimulating desirable agricultural development ( Van der Ban and Hawkins, 1996).

Agricultural extension is the promotion of agricultural technologies to meet farmers needs(Morris, 1991) Extension services involve teaching, research and transfer of new technologies and information to farmers using different media like radio, television, newspapers etc. Technology involves application of mental and physical effort to nature to achieve better value. It is a tool to provide better living condition and enhance the capacity of the people concerned. It is the systematic application of scientific knowledge to practical purposes. It includes inventions, innovations, techniques, practices and material (Okereke, 1983)

Extension systems need to utilize a more scientific framework of information delivery directed at transforming the sector by boosting agricultural production, developing human capital, enhancing rural welfare and broadening the frontier of agro-exports through improved agricultural practices. However, to do this require an information system that is fast, reliable adequate and timely, hence the need for application of ICTs for improvement in the lives of the rural populace to enhance production and thereby alleviate poverty and ensure food security. However, in many developing countries Nigeria inclusive, the extension system has become inefficient due to a wide range of problems. Rivera et al (2001) submit that public extension services have become moribund, due to these deficiencies: accessibility, timeliness of information, funding and cost recovery, usefulness of extension service, ease of adaptability and innovation.

Efforts by public extension delivery systems through the Agricultural Development Programme (ADPs) and private extension services have yielded little results because the problems were not subdued. Against this backdrop this paper focuses on the potential benefit of the application of ICTs to agricultural extension system with a view of enhancing food security and poverty alleviation.

The use of ICT has witnessed an upsurge in recent years in almost all areas of rural life in several African countries despite the persistent problems of access, connectivity, literacy, content and cost (CTA , 2003)

This new development is not without the challenges and opportunities especially in the area of communication to foster food security and poverty alleviation. The changing paradigms in agricultural extension from linear flow of information to pluralistic flow portends that new actors will emerge in the technology transfer pathways. According to ADB (2003), ICT has become a powerful tool in providing developing countries with unprecedented opportunities to meet vital development 
goals far more effective than before especially with the reduction in government involvement in extension delivery.

Madukwe (2006) submits that ICTs may be the only way in which farmers can access a variety of information sources that are accessible, affordable, relevant and reliable. This is because in agricultural extension, the use of ICT is for communicating information/knowledge to farmers with information technology (IT) tools that will facilitate timeliness of extension delivery, leveraging or the electronic speed of processing, converging, transmitting, storing and retrieving information as well as protecting data.

According to Zazueta (2000) and Ndukwe (2004) ICT will foster better, easier and faster access of farmers up-to-date information on market and prices, availability of fertilizers, weather forecasting and pest control. Crop and disease model and prompt information on improved seed. While Sulaiman, (2003) posits that ICT will offer an unprecedented capacity for dissemination of knowledge and information to rural population.

\section{ICT and Poverty}

McNamara (2003) defined the poor as those who lack not only material and financial resources but the opportunities to convert the resources they possess (their labour, skills experience and physical resources) at their disposal into value creating activity (producing either cash income or other resources valuable to their particular livelihoods). They also lack information about resources, tools, processes that could help them be more productive, new opportunities to increase their income, livelihood, market and prices and the availability of institutions on which they depend on their economic exchanges. The poor lack access to education and knowledge that could improve their lives and expand their opportunities, lack access to innovation in products and processes that could increase their efficiency, lack of access to capital, financial resources and services that would permit them to enter into new value-creating activities and lack the power and voice in the institutions that affects their lives, even those designed to help them.

\section{Strategies for Poverty Alleviation with ICTs}

Goals set for 2015 by the international development agencies include reducing by half the proportion of people living in extreme income poverty, those living on less than $\$ 1$ a day. The European Commission suggests that poverty should not be defined merely as a lack of income and financial resources. It should also include the deprivation of basic capabilities and the lack of access to education, health, natural resources, employment, land and credit, political participation, services and infrastructure. (European Commission, 2001). Another analysis adds an even broader definition of poverty to see it as being deprived of the information needed to participate in the wider society, at the local, national or global level.

The assertion that a knowledge gap is an important determinant of persistent poverty, combined with the notion that developed countries already possess the knowledge required to assure a universally adequate standard of living, suggest the need for policies which encourage greater communication and information 
flows both within and between countries. One of the best possible ways to achieve this greater interaction is through the use of ICTs. The most common perception of ICTs is that of computers and the Internet, but many see this as limited, excluding more common technologies of radio and television that also carry information. In particular, the potential value of radio as a purveyor of development information should not be overlooked, especially in view of its almost ubiquitous presence in developing countries, including rural location

A consistent finding of surveys of Internet users and providers in developing countries is that the lack of local language and locally relevant content is a major barrier to increased use. Unless there is a concerted effort to overcome these constraints, Internet growth in many developing countries could be stuck in a lowuse equilibrium (Kenny et al., 2001). The undersupply of pro-poor local content inhibits the virtuous circle whereby as an online community grows, it makes the development of Internet content a more attractive commercial and social proposition, and increasing amounts of attractive content encourage the growth of the online community. Local content is directed towards the information needed to satisfy the communities' needs, and is developed in collaboration with the local people

\section{Agriculture support}

Research suggests that increasing agricultural productivity benefits the poor and landless through increased employment opportunities. As the vast majorities of poor people lives in rural areas and derive their livelihoods directly or indirectly from agriculture, support for farming is a high priority for rural development. ICTs can deliver useful information to farmers in the form of crop care and animal husbandry, fertilizer and feedstock inputs, drought mitigation, pest control, irrigation, weather forecasting, seed sourcing and market prices. Other uses of ICTs can benefit farmers, enabling them to participate in advocacy and cooperative activities.

\section{Disadvantaged group}

Women in developing countries particularly, face difficulties in using ICTs, as they tend to be poorer, face greater social constraints and are less likely to be educated or literate than men. They are likely to use ICTs in different ways, and have different information requirements, to men. Women are less likely to be able to pay for access to ICTs, either because of an absolute lack of funds or because they lack control of household expenditure. Constraints on women's time or their movement outside of the home can also reduce their ability to access technologies (Marker, et al. 2002). Such groups usually require special assistance and attention in order to benefit from programmes that are targeted at poor people

\section{Local entrepreneurship}

ICTs have been claimed to potentially have an impact on the livelihood strategies of small-scale enterprises and local entrepreneurs in the following areas:

- Natural capital; opportunities for accessing national government policies. 
- $\quad$ Financial capital; communication with lending organizations, e.g. for microcredit.

- Human capital; increased knowledge of new skills through distance learning and processes required for certification.

- Social capital; cultivating contacts beyond the immediate community.

- $\quad$ Physical capital; lobbying for the provision of basic infrastructure.

Small-scale entrepreneurs in developing countries, especially women, have shown the ability to harness ICTs for developing their enterprises. ICT and e-commerce are attractive to women entrepreneurs (who in many developing countries account for the majority of small and medium-size enterprise owners), allowing them to save time and money while trying to reach out to new clients in domestic and foreign markets (UNCTAD, 2002).

\section{Capacity building}

The meaning of the term capacity building seems to vary according to the user, but there seems to be no doubt that ICTs are capable of helping to achieve it. There are many definitions, but they all carry the same theme concerning developing an organization's (or individual's) core skills and capabilities to help them achieve their development goals. This definition suits the context of ICTs well as it assumes knowledge of the existence of development goals, without which ICTs are unlikely to be of much value.

Capacity building also relates to the accumulation of social capital, which refers to those features of social organization such as networks, norms, and social trust that facilitate coordination and cooperation for mutual benefit and establishing networks for mutual benefit that can be nurtured and extended through the use of ICTs. ICTs can help create and sustain online and offline networks that introduce and interconnect people who are working toward similar goals. Many NGOs can use ICTs as an advocacy tool to champion their courses.

\section{Employment opportunities}

Two areas of employment opportunity arise from the deployment of ICTs. First, unemployed people can use ICTs to discover job opportunities, and second, they can become employed within new jobs that are created through the deployment of ICTs. Poor people in rural localities lack opportunities for employment because they often do not have access to information about them. One use of ICTs is to provide on-line services for job placement through electronic labour exchanges in public employment service or other placement agencies. The greater transparency enabled by ICT opens up possibilities for more precise information to job seekers. Through open job seeker banks, for example, employers can search and directly access résumés, which, in turn, are linked electronically to job vacancy banks. 


\section{Health}

Health care is one of the most promising areas for poverty alleviation with ICTs, based largely as it is on information resources and knowledge. There are many ways in which ICTs can be applied to achieve desirable health outcomes. ICTs are being used in developing countries to facilitate remote consultation, diagnosis and treatment. Physicians in remote locations can take advantage of the professional skills and experiences of colleagues and collaborating institutions (DOI, 2001). Health workers in developing countries are accessing relevant medical training through ICT-enabled delivery mechanisms. Several new malaria Internet sites for health professionals include innovative "teach and test" selfassessment modules. Centralized data repositories connected to ICT networks enable remote healthcare professionals to keep abreast of the rapidly evolving stock of medical knowledge. When applied to disease prevention and epidemic response efforts, ICT can provide considerable benefits and capabilities. Public broadcast media such as radio and television have a long history of effectively facilitating the dissemination of public health messages and disease prevention techniques in developing countries. The Internet can also be utilized to improve disease prevention by enabling more effective monitoring and response mechanisms.

The World Health Organization and the world's six biggest medical journal publishers are providing access to vital scientific information to close to 100 developing countries they otherwise could not afford. The arrangement allows almost 1,000 of the world's leading medical and scientific journals to become available through the Internet to medical schools and research institutions in developing countries for free or at deeply reduced rates.

\section{ICT and Food Security}

Food security refers to a situation where all members of a household have access to sufficient, safe and nutritious food at all times to meet their dietary needs and food preference for an active healthy life (Nair, 1995). This is a very important phenomenon in poverty alleviation and many households get involve in income and non income generating activities to ensure food security. The extent of food insecurity in the world is reported to be high especially in developing countries as one sixth of the world's population does not have access to sufficient food (FAO, 1995). Food security is dependent on availability, accessibility, adequacy and acceptability of food at all times (FAO 2004). To address the food security needs of Nigerians, the Federal Government of Nigeria set up a Special Programme on Food Security (SPFS). The programme offers a practical vehicle for piloting and extending the application of innovative low cost approaches towards improving the productivity and sustaining the ability of the agricultural systems in Nigeria. It aims at providing alternatives for income generation and improved livelihood, an initiative targeted to halving the number of those hungry in the world by 2015 FMANR/FAO(2006)

ICTs have tended to impact more on the way of life of all people including farmers due to its fast development and vast application. Most farmers possess cell 
phones. Those who have access to IT have more advantage than those who have limited access(Ghatak 2002). There is a clear relationship between information, agriculture and development. Information, together with inputs, market, prices infrastructure, credit and technologies form essential ingredients for development. The proper integration of IT into agriculture would ensure food security; this may be through the development of a multi level decision support model for synergizing the natural resource system with economic and social imperatives and improve efficiency of agricultural research and development through provision of a good data base. Farmers' ability to use ICT should be encouraged through various educational programme (e.g. through village viewing centres).

The development of ICTs is expensive but with the cooperation from all stakeholders many of the hurdles in rolling out infrastructure and ensuring access can be overcome.

Internet technology could be used as a two-way communication tool for transferring production economic information from government agencies to farmers and farmers could also communicate among themselves (cell phones)

ICT can be used for agricultural soil environment information, data base, national agro-meteorological network, pest management, while planning and management of development project could be based on ecological zones delineating the suitable area for selected crop.

\section{CONCLUSION}

The job of extension agents is made easy with ICT. Activities such as land preparation, how to access credit on line, getting improved seed and species, experience sharing, sales of products, market information, forecast, cooperatives formation can be made possible through the use of ICTs because it takes development to people with less physical presence, reinforcing that information is power and that what the farmer need most is access to the right kind of information.

It is the position of this paper that ICT has a lot of potentials for the dissemination of proven technologies and these potentials should be tapped. Both public and private sector should take maximum advantage of ICT for poverty alleviation. A National agricultural policy that would lay emphasis on the use of ICT for achieving a more rapid development of agriculture in Nigeria is advocated. 


\section{REFERENCES}

ADB (2003) A Strategic Approach to Information and Communication Technology. Toward e-development in Asia and the Pacific. Asian Development Bank, Nov 2003.

CTA (2003) Spore Magazine.

DOI Force (2001). Digital Opportunities for All: Meeting the Challenge. Report of the Digital Opportunity Task Force, 11 May 2001. http://www.dotforce.org/reports/DOT Force Report V 5.0h.pdf

European Commission, Communication from The Commission to The Council and the European Parliament. Information and Communication Technologies in Development. The role of ICTs in EC development policy, Brussels, 14.12.2001 COM (2001) 770 final

Food and Agriculture Organisation (1995) Food Nutrition and Agriculture: Alimentation, nutrition and Agriculture, From farming to Security Rome, FAO No.119 pp4-12.

Food and Agriculture Organisation (2004) Improving Nutrition through Home Gardening. A Training Package for preparing field workers in Nigeria. FAO, Rome

Federal Ministry of Agriculture and Rural Development (FMARD) /FAO (2006) National Programme for Food Security (NPFS) Expansion Phase Project 2006 to 2010 Main Report, FAO/UN-Rome, Investment Centre Division TCP.

Greenidge, C. B. ( 2003) ICTs and the Rural Sector in the ACP States. Mirage or Marriage: Feature Address delivered at the CTA ICT Observatory 2003

Ghatak, M. (2002) Use of information Technology in Agriculture. PGPABMHyderabad,manage.

Kenny, C. Navas-Sabater, J. Qiang C., Information and Communication

Technologies and Poverty, in World Bank, Poverty Reduction Strategy Sourcebook, 2001. http://www.worldbank.org/poverty/strategies/chapters/ict/ict0409.pdf

Marker, P., McNamara, K., and Wallace, L. (2002) The Significance of Information and Communication Technologies for Reducing Poverty, The Think! Programme, Development Policy Department, Department of International Development, January 2002.

Madukwe, M.C.(2006) Delivery of Agricultural Extension Services to Farmers in Developing Countries. Issues for Consideration. "Knowledge for Developemt"Observatory on Science and Technology.http//knowledge cta.int/tr/content/view/full/3009. 
McNamara, K. S. (2003) Information and Communication Technologies. Poverty and Development: Learning from Experience " Background Paper prepared for the infoDev.annual symposium, December 9-10, 2003, Geneva Switzerland.

Morris, S. J. (1991) Extension Alternatives in Tropical Africa. Agricultural Administration Unit. Occassional Paper No.7.Overseas Development Institute. London.

Nair,O.S.(1995) An Evaluation of the structure and Function of Tropical Home Garden. Brazil, Kathleen Landauer and Mark Press pp1-25.

Ndukwe, E.C.A. (2004) Information and Communication Technology Science and Medicine in the @ ${ }^{\text {st }}$ Century Nigeria. Paper delivered at a Landmark Public Lecture .event held by College of Medicine, University of Nigeria, Enugu Campus.

Okereke, H. E. (1983) The Role of Extension in Technology Development and Transfer. Proceedings of a Training Workshop on Rural Agricultural Extension. NRCRI, Umudike, Nigeria Pp 79-82.

Rivera, W. M, Qamar,M.K. and Crowder, L. V. (2001) Agricultural and Rural Extension Worldwide. Options for Institutional Reform in Developing Countries. Rome, Food and Agriculture Organisation FAO.

Sulaiman, R. V. (2003) Innovation in Agricultural Extension in India. Food and Agriculture of the United Nations FAO.

UNCTAD. United Nations Conference on Trade and Development E-Commerce And Development Report 2002. http://r0.unctad.org/ecommerce/ecommerce en/edr02 en.htm

Van de Ban, A. W. and Hawkins, H. S. (1996) Agricultural Extension. Second Edition. Oxford Blackwell.

World Bank (2002). Using information and communications technology to reduce poverty in rural India, PREM Notes, Poverty Reduction and Economic Management Network, No.70, June 2002. http://www1.worldbank.org/prem/PREMNotes/premnote70.pdf

Zazueta, A. (2000) The Agricultural Extension Service and Information Technology in the $21^{\text {st }}$ Century. www.jsai.or.jp/anta.conf/2000/portal/pol.pdf 